\title{
The Tradition and Ideology of Naming Seleukid Queens
}

\begin{abstract}
AвSTRACт: This article examines the traditions and ideology which guide the Seleukid dynasty's faithful repetition of female names over various generations as a case study for better understanding Hellenistic royal onomastics. Beginning with a review of the function of Greek personal names more generally, the article then examines the mechanics behind repeating royal female names. The name Laodike is then taken as a case study, and is examined in relation to Seleukid mythology, royal cult, and the longer literary tradition stretching back to Homer. A reconstruction is then proposed, in which it is argued that female names functioned as quasi-titles.
\end{abstract}

Keywords: Seleukids - Onomastics - Royal Women - Hellenistic history

\section{Introduction:}

Much to the mutual chagrin of undergraduate students studying for their exams and researchers trying to disentangle frustrating webs of descent, the royal dynasties of the Hellenistic Period have fairly narrow tastes in the names they give to their male and female children. 'The phaenomenon is as visible among the main successor dynasties of the Ptolemies, the Seleukids, and the Antigonids as it is among the secondary or subordinate dynasties of the period, like the Mithridatids of Pontus or the Ariarathids of Kappadokia. ${ }^{2}$ In the latter two cases, it is precisely their onomastic repetition that has given rise to their dynastic name in contemporary scholarship. ${ }^{3}$ Yet despite the myriad Laodikai, Kleopatrai, and Stratonikai that populate these dynasties, the question of why exactly Hellenistic dynasts recycled these names with such enthusiasm has largely evaded direct consideration, save for the more 'famous' cases of Olympias of Macedon and

1 An initial draft of this paper was presented at the Hellenistic Queens workshop hosted by the Waterloo Institute for Hellenistic Studies in Canada on 21 October, 2016, and my thanks go to the organiser, Sheila Ager, and all those present for their invaluable feedback. Discussions with Lloyd Llewellyn-Jones (Cardiff) and Elizabeth Carney (Clemson) helped greatly in refining the arguments presented here, as did the comments from Historia's anonymous readers. As for repetitive naming traditions, a small quantitative sample will suffice: according to the Ptolemaic genealogy of Bennett (2011), the dynasty included at least 20 men named Ptolemy, and at least ten women named Kleopatra. The Seleukid genealogy of McAuley (2011) lists 16 women named Laodike, at least ten men named Seleukos, and 17 men named Antiochos.

2 See D'Agostini 2016 on the ties of the Mithridatids of Pontus, and van Dam 2002 along with Ballesteros Pastor 2008. For the most recent examination of the Greco-Baktrian kingdoms in Seleukid times, see Wenghofer and Houle 2016, and Coloru 2009.

3 Hence the Mithridatids of Pontus and the Artiarathids of Kappadokia. 
Kleopatra VII. In this article I shall limit my onomastic examination to the royal women of the Seleukid realm in order to make the topic more manageable, but the questions posed here, along with the approaches taken to resolve them, may equally be applicable to male royalty, as well as to the other dynasties of the Hellenistic world.

The many recent articles, edited volumes, and monographs that have contributed greatly to our understanding of Hellenistic royal women over the past few decades tend to discuss the influence that made a given Hellenistic queen different from others, or how her career made her exceptional in the broader history of the Period. ${ }^{4}$ In this group, monographs on Arsinoë II, Berenike II, and Olympias of Macedon come to mind, as do many re-examinations of the (in)famous actions of Laodike I and the marriages of Stratonike. ${ }^{5}$ In order to shift the focus back to some of the common characteristics of royal women in the period, then, it would seem beneficial to give equal attention to one of the aspects that unites many of them: their names.

These considerations of the ideology lying behind personal names become especially pressing given the wealth of work on other ancient naming conventions that has appeared in recent years. Federicomaria Muccioli’s Gli epiteti ufficiali dei re ellenistici (2013) and the 2011 numismatic study of de Callatay \& Lorber revealed the extent to which the nicknames or epithets given to Hellenistic monarchs were politically, religiously, or martially charged, and bore with them a wealth of associations. The evolution of Roman onomastic practice was thoroughly considered by Benet Salway in 1994, and female praenomina in particular received specific attention in the same year from Mika Kajava. ${ }^{6}$ The work of Gary Farney ( 2007 and forthcoming) continues to unlock the many associations that were coded into Roman aristocratic nomina and cognomina in the Republic.? According to his findings, these nomina carried not only ethnic but also physical, hereditary, or personal traits that originated in the Early or Middle Republic and persisted well into the Imperial Period. More recently, Elizabeth Carney has put forward some observations regarding the contexts in which Olympias, mother of Alexander the Great, changed her name at certain points in the course of her life and her career, to which we

4 On the power of Hellenistic queens generally, see the discussion of Dumke 2013 on the agency of these women at court and beyond, as well as the last legacy of Hellenistic queenship in the Roman world as discussed by Harders 2010. The most prominent examples of this are Longega 1968, Müller 2009, and Carney 2014 on Arsinoë II; Schäfer 2006 and Roller 2010 on Kleopatra VII, and Clayman 2014 on Berenike II along with Caltabiano 1996 and 1996. Several of the contributions to the volume edited by Coskun and McAuley 2016 also detail the careers of individual royal women, especially Apama, Stratonike, and Laodike I. It is noteworthy that this biographical trend towards treating individual royal women in isolation dates as far back as Macurdy 1927 and 1932, who initially approached royal women individually instead of making collective generalisations. There are, of course exceptions to this approach, notably Harders 2013's discussion of the wives of Demetrios Poliorketes, and the analysis of both Stratonike and Apama in Plischke 2016 and Harders 2016. For other general studies see Bielman-Sànchez 2003, Carney 1995, 2005, and 2011, Ager 2005, and Dumke 2013.

5 On Stratonike: Harders 2016, Engels and Erickson 2016, Alamagor 2016, and Ramsey 2016. On Laodike I see Coskun 2016.

6 See Salway and Kajava 1994.

7 The introduction to Farney 2007 discusses the ethnic associations of Roman nomina, particularly with an eye towards transmitted familial characteristics. Farney forthcoming will explore the topic in greater detail in the Late Republic and Early Imperial Period. 
shall turn in greater detail below. All of this research has gone to show, in short, that a name was far more than just a name, and that in the Roman as in the Greek world it bore with it a wealth of attributes that were projected onto its bearer. The same must be the case among such highly visible and publicised figures as Seleukid queens, particularly given how enthusiastically their names were adopted by their subordinates and progeny.

In order to investigate these naming traditions of Seleukid queens and the royal ideology which informed them, I shall briefly consider the place and function of personal names in the Greek world, both in the 'traditional' Mainland and Argead Macedon. I shall then turn to the superficial mechanics of transmitting these female names both within the main Seleukid dynasty and among its client dynasties, and consider their bearing on the ideological integrity and practical administration of the Empire. Turning from these general concerns towards a more detailed analysis of a specific name, I will take 'Laodike' as a case study and consider the literary, historical, and cultic associations of the name, as well as the meaning(s) conveyed by its etymology. Finally, a reconstruction of when and how a Seleukid princess was named will be advanced. My thesis throughout this article is borrowed from the words Plato put into the mouth Kratylos when discussing the topic of onomastics with Socrates. On the subject of names, he argues:

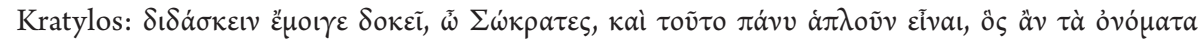

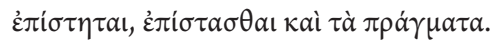

Kratylos: I think, Socrates, their function is to instruct, and this is the simple truth, that whoever knows the names also knows the things themselves.

- Plato, Kratylos 435d.

\section{Personal Names in the Greek World}

As Kratylos generalises above, names in the Greek world function as much more than just designators. While in the $21^{\text {st }}$ century, and particularly in the Anglophone context, little thought tends to be given to a personal name beyond its aesthetic, aural, or familial appeal, in the Greek tradition personal names are embedded with a great deal more information. They serve to instruct, and they bring with them a vast range of individual and collective connotations. Claude Calame is the most recent scholar to have worked extensively on the linguistics and the semiotics of Greek naming conventions in his 1995 monograph The Craft of Poetic Speech in Ancient Greece, building off of observations put forward by German scholars of the 1930s. ${ }^{8}$ Although Calame's research focusses on the Archaic and the Classical Periods, I believe that his conclusions can easily be carried over into the realm of Hellenistic royalty as well. This is only one of many instances in

Originally published in 1986 as Le récit en Grèce ancienne, and then translated into English by Janice Orion in 1995 - whose edition and pagination are quoted throughout. 
which the Argeads and their successors modelled themselves consciously on their Archaic - especially Homeric - predecessors. ${ }^{9}$

While the linguistically-minded Calame is admittedly more concerned with the semiotics of Greek names and their theoretical underpinnings than their historical evolution, the broader import of his observations on Greek onomastics are clear. 'The unambiguous function of the anthroponym', a personal name designating a human being, he writes, 'has been to designate the identity of an individual in a univocal manner', and thus it always functions as a rigid designator in the sense that a it refers uniquely back to only one object (Calame 1995, 174). But this identifying function extends far beyond mere designation: the Greeks, he notes, had always had a particular penchant for playing with the etymologies of names and the multiple readings that can be derived from their components; a habit which is attested as long as there has been a Greek alphabet. In Homeric poetry, this is usually just a matter of associating a hero with the qualities evoked by his (or indeed her) name or by its constituent parts (Calame 1995, 173-178). A sort of play on words, as it were, is at work with almost any name in epic poetry, and one name can have many potential meanings or associations that emerge from its compound parts.

Of course patronymics are the most obvious information coded into Greek personal names, and while their form and function are fairly straightforward, there are more complicated compounds at work in Greek onomastics which carry more detail. These potential associations of a name have traditionally been grouped into three categories by modern grammaticians, drawing on Calame's most recent recapitulation $(1995,176)$ of their work. A Greek name can be formed of a possessive compound, which attributes some quality to the person being named (Eteoklēs - 'one who possesses true fame'). A determinative compound contains two distinct elements, the second of which is defined by the first in what would usually be a genitive construction but in this case is postpositive - i.e. Theodōros meaning 'gift of the god', and Démokleitos meaning 'renowned of or among the people.' The third is the category into which I shall subsequently argue Laodike can be placed: compound names containing a verbal element followed by a second element that is related to the verb, generally as a transitive object. ${ }^{10}$ There are also simpler constructions at work in Greek names in which an adjective or noun simply functions as a proper name as well (Agathōn, Polemōn, etc ...), but altogether this goes to show the vast variety of linguistic functions performed by Greek onomastics. Female names are certainly no exception to this, and neither should the complexity of

Of course the famous anecdote of Alexander sleeping with a copy of Homer under his pillow is a clichéd expression of Macedonian interest in their Homeric predecessors, though not without value. Carney 2000 and 2006 discuss the relationship between Homeric royalty and the Argeads extensively, though passim. A recent examination by D'Agostini 2013 displayed that Polybius was quite aware of similarities between Laodike of Sardis, wife of Achaios the Younger, and Andromache to the point of repeating certain passages and adjectives. The general social structure of the Macedonian and thus Hellenistic world in which a king is surrounded by his hetairoi and philoi, and must keep his power through benefaction and personal military prowess, is very similar to the world of the Homeric epics.

This recapitulation is drawn from Calame's summary at 1995, 176, using his examples. 
Greek onomastics be taken as a distinct phenomenon - such compound proper names appear in several other Indo-European groups spread throughout Western Europe and the Middle East. ${ }^{11}$

A few examples will suffice to illustrate the point, drawing again on the work of Calame along with Nagy (1979), Risch (1947), and Mühlestein (1969). The name of Hektor's son, Astyanax, is a fitting example of a determinative compound which quite literally translates into 'ruler of the city' or 'king of the city', a fitting attribute given his paternity, while the infamous Skylla confronted by Odysseus is rather more simply derived from skylax - 'little dog.' ${ }^{12}$ The associations of these names can be polyvalent as well, as the name Odysseus can be related to two different verbal elements which are equally applicable to his character: first, odyssasthai, 'to be angry with' is a fitting epithet for the wandering hero given that he drew the ire of Poseidon with the murder of Polyphemos; and second, odyresthai 'to mourn, to lament' likewise reflects his longing for Ithaka and his grief at the loss of his comrades at Troy and during the journey home. Other Homeric names, however, are a bit more complex and reveal some sense of irony in the appellation of an individual. Astyanax again exemplifies this trend because although he was destined by birth to be a prince of Troy, this potential was of course never realised. The same goes for Andromache, 'destroyer of men', who herself is not responsible for the death of any men but rather suffers because of the loss of Hektor.

These onomastic allusions are not limited strictly to epic poetry. Hesiod (Theog. 195200) mentions how Aphrodite's name is derived from aphro-genēs, 'born of the foam', and uses these etymological explanations to introduce various other deities in the Theogony. ${ }^{13}$ The tendency continues in tragedy with characters like Élektra - 'without a marriage bed' and thus 'the unmarried one', fitting given her place in the House of Atreus during the Oresteia. Other examples abound, but the pattern remains the same: even from the earliest period of Greek literature there is a clear tendency 'to make a proper name into a metaphor of sorts' which does not merely identify an individual, but conveys some aspect of their character (Calame 1995, 178).

When we turn to the poetry of Alkman we see that personal names can signify something beyond the individual by reflecting civic values or ideals - especially those associated with women. ${ }^{14}$ This appears quite clearly in fragments 1 and 3 of the poet: after a scene from Sparta's mythic history and several lines praising the qualities of the khoregos, the young women who sing the poem name themselves: Nannō, 'the little doll', Areta, 'excellence' or 'the excellent woman', Phillula, 'the beloved child', Damareta, ' excellent in the city' or 'excellent in the demos', Kleèisthêra, 'famous for hunting', all of this associated with some aspect of civic virtue or beauty. Interestingly, as Alkman goes on to

13

14

Calame 1995: 176-177 and note 6, see also Cardona 1980, 139, and Durante 1976, $2.102 \mathrm{f}$.

\footnotetext{
These examples are drawn from the discussion of Calame 1995, 177, who himself is drawing on the work of Risch 1947, 72-91 and Nagy 1979 passim.

For instance, Kymatolege and Amphitrite (Hes. Theog. 252-265).

The fragments of Alkman are 1 and 3, discussed in great detail by Calame 1977 volume II, especially 45133. See also Calame 1977 volume I for the socio-cultural background of these archaic female choruses.
} 
narrate, none of them alone can rival the beauty of the khoregos, but in the ensemble we can see many of the most cherished virtues of Archaic Sparta reflected onomastically. ${ }^{15}$

There is no reason to think that Sparta was unique in using female personal names as metaphors for civic, communal, or even familial virtues, and this use of female onomastics as an advertising or normative tool of sorts is common across the Archaic and Classical Period. This trend of naming aristocratic and citizen women after civic virtues is such a prevalent trope that it could even be exploited by prostitutes and their enterprising madams. In Demosthenes 59 (Against Neaira, 18-19), an easily-overlooked anecdote appears in which Nikaretē, the madame and owner of the brothel, would recognise the budding beauty of young slave girls who showed lucrative promise to her clients. ${ }^{16}$ Raising them herself and educating them artfully, she would then give them the names of free, aristocratic women - Aristokleia, Anteia, Stratola, Metaneira, and the like, whose metaphorical meanings are not difficult to discern (Dem.59.19). Thanks to this combination of naming and upbringing, these prostitutes could masquerade as young daughters of citizens or even the elite, and thus fetch a higher price from their lovers as a sort of fetish. In satire the tone of these associations certainly changes, but the mechanism remains the same.

The process of naming a Greek woman, in the Classical Period as in the Hellenistic, is unfortunately much more difficult to determine than the metaphorical associations of the names themselves. There are two models that may be proposed regarding when and how women like our Seleukid princesses would be given their personal names, and it would seems that the latter scenario I present would be more likely than the former. The first draws on the parallel of male citizen names in Classical Athens, according to which a young baby, male but presumably female as well, would be given a name publically by its parents when it was still a new-born as part of the public recognition of the legitimate child by the community. In the process, the name itself, to quote Calame, 'projects the values the name denotes onto the child's future' (1995, 181-182). Accordingly, women like our Seleukid Laodikai would be given this name by their parents in fairly short order after their birth, with the implicit expectation that they would grow to embody all that the name carried with it.

The second is perhaps more probable in the Seleukid context, and rather more enticing as well. In her monograph on Olympias, mother of Alexander the Great, Elizabeth Carney $(2006,15-16)$ makes several observations regarding the various names associated with the woman that likely apply to Seleukid women as well. Besides Olympias, Plutarch (Mor.401B) relates that she was also known as Polyxena, Myrtale, and Stra-

15 All of these examples and etymologies again taken from Calame 1995, 179-183.

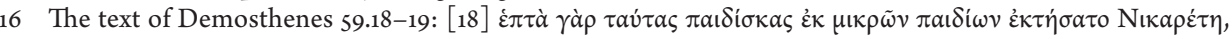

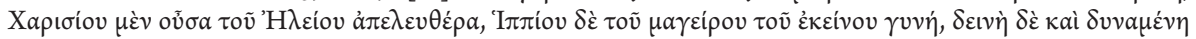

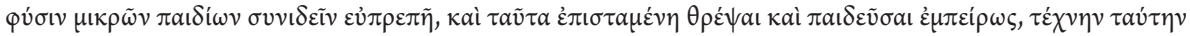

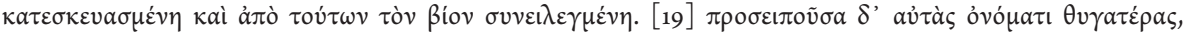

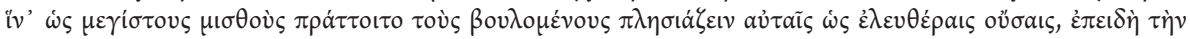

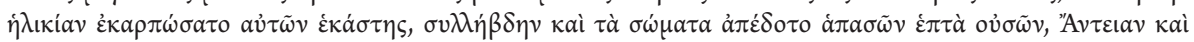

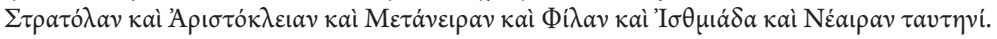


tonike, while Justin (2.7.13) clarifies that she was initially known as Myrtale during her childhood. Olympias thus changed her name at least once, and perhaps several times, over the course of her life at significant moments such as betrothal, marriage, or motherhood (Carney 2006, 16). Carney's reconstruction of this sequence illuminates the myriad concerns that went into a royal woman's name. She was first called Polyxena, a Trojan name which both fit into the trend of her current generation and further reinforced her family's purported ties to the House of Priam, and to Neoptolemos. ${ }^{17}$ Carney surmises that at some point before her marriage, perhaps during her adolescence, she assumed the name Myrtale in connection with either a rite of passage, a Samothracian ritual, or a mystery cult. ${ }^{18}$ The change of her name to Olympias must thus date to around the time of her marriage to Philip II, which was somehow connected to a festival of Olympian Zeus, and/or Philip's Olympian victory in the year after their wedding. Stratonike is the last name attested for the queen and likely the most epithetical: given its obvious military valence, it probably emerged from the brief period in which she was victorious against Adea-Eurdyike and Arrhidaios, before falling victim to Kassander. ${ }^{19}$

In the name of Olympias we see not only the plasticity of royal female names, but also the diverse concerns that informed their selection: heroic ancestry, dynastic continuity, and familial trends are the likely suspects, but the religious attachments of both the woman herself and her husband can be equally determinative, while a name like Stratonike seems to be more of an epithet than a personal name per se. Marriages, victories, and cult activities all manifest themselves in a royal woman's name, but this raises the fundamental question of agency: were women like Olympias in control of their own names, or were they determined by the men in their lives, either their fathers, husbands, or brothers? Sarah Pomeroy takes this one step further by considering whether Olympias herself would have been in favour of these various onomastic shifts, which could have either strengthened her bond with Philip or resulted in the loss of a sense of her personal identity (Pomeroy 1984, 10). Carney brings a level of nuance to this by asserting that all of these names were not necessarily foisted on her, but that she might well have chosen them herself $(2006,16)$. Myrtale could have been a personal choice informed by devotion, akin to a Roman Catholic's choice of their confirmation name, and Stratonike would likewise have been a positive affirmation of her (temporary) military success.

17 See Carney 2006, 146 note 81 for the full discussion of the relationship between Olympias' family and Neoptolemos. Polyxena, as Heckel 1981 has noted, is connected to Neoptolemos in myth, though this is a fairly bloody association given that he murdered Polyxena. The alternative reconstruction is that the name 'may reflect the heroic character of Polyxena in Euripides' Hecuba and that it may have been a common name in the Chaonian dynasty' (Carney 2006, 146 note 81 discussing Mortensen 1997, 25).

18 See the extensive citations and bibliography Carney provides in Carney 2006, 16 and notes 79-85 of this chapter. Carney 2006, 16 connects this name Myrtale to a mystery cult, but Mortensen 1997, 26-29 views it rather as being connected to a puberty rite in honour of Aphrodite, thus a coming-of-age ceremony.

19 As later scholars have surmised following Heckel 1981, 85, the name Stratonike was chosen fairly soon before Olympias died and thus did not have enough time to enter common usage. Accordingly, she was known primarily by her married name of Olympias. Perhaps if she had survived longer after re-naming herself Stratonike then she would have been attested under this epithet rather than Olympias. See Carney 2006, 146 n. 84 . 
Polyxena and Olympias, meanwhile, would have been names chosen for her by others, namely her father in the former instance and her husband in the latter. While this question of the agency behind royal names may perhaps never be resolved, an observation made by Carney $(2006,16)$ about their purpose is of fundamental importance in the Seleukid context: 'these significant names may sometimes have functioned as quasi-titles in an era before actual titles were employed' - thus the dynastic name becomes the title of queen avant la lettre. ${ }^{20}$

To sum up before turning to the Seleukids themselves, this review of Greek onomastics has indicated that throughout Greek history a personal name was a great deal more than simply a designator. From the Homeric period onwards, both male and female names can indicate everything from paternity to personal narratives and individual character traits or expectations. Collective civic or aristocratic virtues can be encoded into a name, as we have seen in the poetry of Alkman, while over time certain names take on associations with a specific aristocratic lineage or a status group - such as the free citizen women of Athens. In the royal context of Macedon, the performative aspect of personal names is heightened, as is their plasticity: royal names can change over the lifetime of a woman such as Olympias in response to various contemporary concerns, guided by either the woman herself or the men with whom she is associated. All of this would seem also to apply to the Seleukid women we shall consider below: the names may well have changed at certain moments of their lives, and their names carried with them associations of the dynasty's ancestry, its religiosity, and its political prominence. When these family names are granted over subsequent generations, their function as quasi-titles or epithets becomes more pronounced, as Calame writes:

as a category, Greek anthroponyms assume, in addition to their role in identifying individuals, the classification function that anthropologists attribute to them, with good reason. Because of the qualities they designate, they often confirm social status that family origin automatically confers on the newborn $(1995,178)$

\section{Links in the Chain: Repetitive Names.}

Bearing all of this in mind, we turn now to the 'superficial' mechanics of these royal names by considering their simple repetition over subsequent generations of the family. As has been recently elaborated, in order to make itself seem more coherent, stable, and identifiable, the Seleukid royal family often presented itself as a simplified nuclear family, a 'reigning triad', as it were, composed of a king/husband, queen/wife, and heir/ son. ${ }^{21}$ Even though there were frequently many other children in a given generation,

20 For the development of royal titles for women, see Carney 1991.

21 This idea of a simplified view of the Seleukid royal family was first touched on by Carney 2011, 205, and the role of women in legitimation of monarchs and thus the family is discussed by Nourse 2002, 227-228. For the conception and administration of the Seleukid Empire as an oikos, see the important contribution of 
the dynasty tended to present itself in this simplified form with three components as a means of clarifying legitimacy and succession. Though the precise constituents of this reigning triad could change within a single generation, as occurred with the allegedly rebellious son of Antiochos I and Stratonike, but the coherence of the image remains the same. While the detailed dynamics of this triad need not preoccupy us here, the function of the device is clear: it serves to preserve and perpetuate dynastic continuity from one generation to the next, presenting the family as a close-knit entity. Examples of this projected image of family unity abound across various media, ranging from the cities of the Tetrapolis in Syria which simultaneously represents two generations of the Seleukid dynasty, to the Antiochos I Cylinder from Borsippa, in which Antiochos' other children are glossed over and he is presented only with his son Seleukos and wife Stratonike who herself is described using nuanced vocabulary of partnership and divinity. ${ }^{22}$ This proclivity for a reigning triad also presents itself in the marital re-arrangements of Antiochos IV, who tried to step into the dynastic vacancy left by the death of his brother, and then took great pains to communicate this continuity through his coinage. ${ }^{23}$ From coins and cylinders to cities, the Seleukids go to great lengths to emphasize the stability and coherence of the family across various media, and I argue that this ideological programme is also manifested in the dynasty's rather limited choice of personal names for its male and female members.

While there are some attested instances of Seleukid kings bearing another name before they came to the throne, in general the names Seleukos and Antiochos are so prevalent that they seem almost to be regnal names assumed when a Seleukid prince was designated heir, co-regent, or took the throne. ${ }^{24}$ The notable exception of Demetrios I and

Coloru 2011, and on the Hellenistic world more generally, Schmitt 1991. Also see the discussion of McAuley 2012, 18-36 on the evolving dynamics of the nuclear family, and D'Agostini 2013.

22 For the ideology and situation of the Syrian tetrapolis, see Grainger 1990, 68-105. With regards to the Antiochos I Cylinder, I follow the analysis of Kuhrt and Sherwin-White 1991, with their detailed consideration of the terms hirtu and sarratu.

23 See the relevant discussion of Dodd 2009 and Mittag 2006.

24 There are two principal cases of this: first, Seleukos III Keraunos is attested by Eusebius Chron. 1.40.11 as originally having been named Alexander, but then he assumed the name Seleukos when he became king. In the other attestations of his reign (Porphyry F.32.9, App. Syr. 66-68, Pol. 32.71.4) he is referred to as only Seleukos, so the name change was by all accounts effective and enduring. For full ancient and modern references, see the relevant entry in McAuley 2011 and Grainger 1997, 20. The other case is the question of whether Antiochos IV was originally named Mithridates, emerging from an inscription from Herakleia, dated to 198/197 (SEG 37.859), which lists three sons of Antiochos III: Antiochos, Seleukos, and Mithridates. Another Mithridates is mentioned by Livy 33.19.9. For the full scholarly discussion see Mittag 2006, 34-37, with detailed references to the above inscription at notes 4-6. According to Mittag's convincing arguments, the Mithridates attested as a son of Antiochos III is identical to the man who would later go on to rule as Antiochos IV, providing another instance of a name change upon royal succession. As with Seleukos III, though, once he is king, he is only attested as Antiochos, further reinforcing this idea that it is a regnal name. There is another case that is somewhat more nebulous: a Babylonian tablet dated to the reign of Antiochos II (Sachs and Hunger 1989, no.245 A obv. 13) refers to a child of Antiochos II named 'Apammu.' While on the surface it is uncertain if this Apammu would be a daughter (Apamma) or son (Apammes) of the king, according to the arguments of Sherwin-White and Kuhrt 1993, 126 and Grainger 1997, 13 and 38 , it seems more likely that the name should be read as female, thus indicating a daughter of Antiochos II named Apama. Furthermore, it would seem odd that this early generation of Seleukids would 
II can be explained through a possible Antigonid marriage connection to Philip V, according to the hypothesis of Jean Helliesen, and thus the appearance of two men named Demetrios in the second century represents the adoption of another dynasty's typical male names. ${ }^{25}$ Alexander Balas and Zabinas are generally held to be pretenders to the throne, and thus we can remove Alexander from the list typically Seleukid male names. ${ }^{26}$ With these exceptions aside, the resulting message given by this repetition of male and female names among the reigning Seleukids is simple: another generation, another nuclear family, another king, queen, and successor, but still bearing the typical names of the same family which is trying to ensure the perpetuation of its dynastic power.

The role of royal women in this Seleukid construct as the transmitters of legitimacy and the beacons of the family's prestige has been the subject of an increasing body of research, and their resulting prominence is as clear in this dynasty as among the Antigonids and the Ptolemies. This onomastic continuity of female names, thus, would also seem to be another part of this role. Hence in the early Seleukids we see the transmission of names like Laodike (the mother of Seleukos I), Apama (the mother of Antiochos I) and Stratonike (the wife of both Seleukos I and Antiochos I) among the first generation of royal daughters. ${ }^{27}$ Given this emphasis on legitimacy and continuity, it comes as little surprise that the daughters of Seleukos I would be named Apama and Laodike, thus including female names from the patriline as well as the matriline, while

choose to make a female name of the dynasty's matriarch into a masculine name and give it to one of its princes, particularly given the feminine ending form of the name in Greek. This generation of Seleukids is also discussed by Ogden 1999, 127-131.

25 See the relevant entries for Demetrios I and II in Grainger 1997 and McAuley 2011. The hypothesis that the name Demetrios indicates an Antigonid connection rests on the unique appearance of this quintessentially Antigonid name suddenly in the second century, as well as the uncertain identification of Laodike IV's parentage. Helliesen 1981 has discussed this context in great deal, and hypothesised that the name Demetrios was an attempt by the Seleukids to claim the Macedonian throne. According to her argument, Seleukos IV would have married an Antigonid princess who was the daughter of Philip V of Macedon. Regardless of whether this specific line of descent is the case, it does seem that there was some kind of renewed marriage connection between Seleukos IV and the Antigonids, and the adoption of Demetrios can be viewed as a temporary re-advertisement of these older dynastic ties. In a similar vein, the recurrence of the name Demetrios in these generations, as well as the son of Demetrios I named Antigonos and much later Demetrios III and the Seleukid Philip (son of Antiochos VIII and Kleopatra Tryphaena) suggest that the reign of Antiochos IV and later Demetrios I produced two competing branches of the dynasty whose struggle for supremacy would never be resolved. Antiochos IV and later Demetrios I, as attested by Jos. AJ.13.390, App.Syr. 47, 66-67, and Pol. 31.2.9-11, attempted to tie off the dynastic loose ends left by their respective successions to the throne, though neither were fully successful. It follows logically that the period produced two lines within the dynasty, one 'Antigonid' branch from Demetrios I, and the other 'Antiochid' branch from Antiochos IV. On the development of these two branches, see also McAuley 2012. 28-35.

26 For the full scholarly history of Alexander Balas' descent, see the discussion of Ogden 1999, 143-145, and Dodd 2009, 99-103. Regardless of his actual paternity, he was not widely accepted as a legitimate king by the ancients and did not attempt to take a typically Seleukid regnal name. On Alexander Zabinas, see Ehling 1995 and 1996, though by all accounts the testimony of Justin 39.1 that his father was Protarchos, a merchant, seems the most likely given the Aramaic nickname - Zabinas - that was given to him, meaning 'the bought or purchased one'.

27 See the respective entries in McAuley 2011, Grainger 1997, and Ogden 1999 for the attestations of these various children. In this article I follow the numbering and heredity outlined by McAuley 2011. For the attested daughters of Seleukos I see Malalas p.198, Eustathius 915, and Ogden 1999, 119. 
the pattern continues in the next generation with the daughters of Stratonike and Antiochos I being named Stratonike, Apama, and Laodike. ${ }^{28}$ The same three female names are likewise present among the daughters of Antiochos II and Laodike in the next generation of the family. ${ }^{29}$ This consistency of course applies to male offspring as well, who are all named either Seleukos or Antiochos, and the message is clear: even in the first three generations of the family as the glue of other royal traditions had yet to dry, these names are already consistent to the point of having become a distinctly Seleukid trademark..$^{3 \circ}$ Continuity, again, lies at the core of this mechanism: the smooth transmission of legitimacy and power from one generation to the next is mirrored by the transmission of these names. In this, the Seleukids are certainly no exception, as we find the same pattern among the early Ptolemies and Antigonids as well.

Where the Seleukid case becomes particularly interesting, however, is in the naming habits of the Empire's 'client' or subordinate dynasties: the so-called 'House of Achaios' in southern Asia Minor, the Mithridatids of Pontus, the Ariarathids of Kappadokia, and the Graeco-Baktrian dynasties of the East. ${ }^{31}$ Despite the vast territorial divides separating them, these client dynasties are united by two common traits: first, they all received a Seleukid princess in marriage as confirmation of their loyalty to the main dynasty, and as soon as the subsequent generation of the family they all adopt Seleukid names - but only the female names. In Pontus, for instance, we find the marriage of Laodike, daughter of Antiochos II and sister of Seleukos II, to Mithridates II at some point in the 240s or 230 . $^{32}$ Thereafter, every identifiable queen of the dynasty is named Laodike for the next four generations until the fall of Mithridates VI Eupator, while male offspring are all named Mithridates. The same is true of the 'House of Achaios', as it has been called by D’Agostini and McAuley, the cadet dynasty ruling over Seleukid affairs in Asia Minor from the 28 os until the revolt of Achaios the Younger in 216. It was precisely the prominence of the name Laodike over three to four generations of this family which initially led to the hypothesis that they must have been related to the main Seleukid dynasty by marriage, likely during the lifetime of the dynasty's patriarch, Achaios 'the Elder'. ${ }^{33}$

28 Stratonike, daughter of Antiochos I: Justin 28.1.2, Eus.Chron.1.249; Apama, daughter of Antiochos I: Paus.1.7.3, Por.F32.5, Eus.Chron.1.40.5. Note that both are attested when they are married.

29 Again, Laodike, daughter of Antiochos II and Laodike I, is attested only at the time of her marriage: Eus. Chron.1.40.6, Justin 28.5.3, Grainger 1997, 48. The same is true of Stratonike, who married Ariarathes III of Kappadokia: Diod.31.19.6, Por.F32.6, Macurdy 1932, 86.

30 For male naming patterns, take, for instance, the ill-fated brothers Seleukos II and Antiochos Hierax: Diod.31.19.6, Justin 28.5.3. To emphasize this continuity in naming traditions, we can identify them patronymically as 'Seleukos and Antiochos, son of Antiochos, son of Antiochos, son of Seleukos, son of Antiochos' over the preceding generations.

31 See notes above for discussions of each. On the 'House of Achaios' in particular, see the entry of D'Agostini and McAuley 2012, along with the article by D'Agostini 2013, and McAuley forthcoming.

32 For the marriage of Laodike to Mithridates II: Eus.Chron.1.40.6, Justin 28.5.3, Grainger 1997, 48. Coskun 2016 presents a revised chronology of the preceding generation as well as of the War of the Brothers, and would argue for a different date for this marriage. Regardless, the dynamics of descent remain the same.

33 For the full reconstruction of this family and hypotheses of different lines of descent, see the entries of D'Agostini and McAuley at http://www.seleucid-genealogy.com/Achaeus.html. Also, McAuley 2015 discusses digital methods of determining these vectors of descent. 
This client dynasty produced five women named Laodike and one named Antiochis, thus the pattern clearly holds here as well. The same occurs among the Ariarathids of Kappadokia, who adopt the name Stratonike while intermarrying with the Seleukid house over the course of two generations. ${ }^{34}$ As Richard Wenghofer and D.J. Houle have recently demonstrated (2016), the name Laodike appears in Baktria as a means of legitimating the rule of Eukratrides, leading to the hypothesis that there was an unattested Seleukid princess who married into this family at some point in the third or early second centuries. In the famous coinage of Eukratides, the fact that only Laodike, not Heliokles, is pictured with a diadem implies that this Baktrian king was claiming his right to the throne by his mother's line alone, not his father's. ${ }^{35}$ Here in the East as well, we thus find another instance of a Seleukid princess named Laodike acting as a king-maker, and being paraded as a beacon of legitimacy.

While other examples continue to appear as late as the dynasty of Kommagene, the pattern and its mechanics remain clear and consistent. ${ }^{36}$ The names Laodike, and Antiochis, along with Stratonike and Apama in the early generations, become associated with the Seleukid dynasty and its legitimate pedigree stretching back to the mother of Seleukos I. In no small part because of the prestige and renown attributed to Seleukid royal women, those client dynasties which married into the main house kept their male names, but tended to immediately adopt Seleukid names for subsequent generations of royal women. This imitation, it seems to me, was meant to advertise and re-advertise their hereditary link to their imperial overlords of the powerful main dynasty. This advertisement in turn works to their domestic benefit: it was precisely because of these dynastic marriages and the recognition from the Seleukid king they conferred that these client dynasts were able to claim sovereignty in their own domains. The adoption and repetition of Seleukid female names further demonstrates that these links of heredity and loyalty were renewed from generation to generation, and that these marriages along with the alliances they solidified were not simply instantaneous affairs. In advertising their Seleukid connections, the kings of Anatolia, Pontus, Bithynia, Kappadokia, and Baktria were also trumpeting the key source of their own basileia through onomastics.

In the main house as well as in the client dynasties, the trend continued over time and the number of royal women bearing Seleukid names multiplied, to the point that by the Roman Imperial Period we find royal and elite families alike with the name Laodike featured prominently. It seems that the ideological importance of these early generations of Seleukid women set the trend which was eagerly perpetuated by their progeny and their imitators. Particularly before the widespread adoption of the title basilissa, as Carney has demonstrated in the Argead case, names like Laodike in the Seleukid realm become quasi-titles by the second century that are shorthand for 'queen' or 'princess', in this case a specifically Seleukid queen or princess. By thus giving these women the same

Diod.31.19.6 for the marriage itself, also analysed by Macurdy 1932, 83 and Bevan 1902, 2.57-9.

35 A hypothesis fully developed by Wenghofer and Houle 2016, 195-209, with images of relevant coin issues.

36 See Strootman 2016 for a discussion of the descent of Antiochos I of Kommagene as outlined in the Ahnengalerie of Nemrut Dag. 
Seleukid names, their families ensured that they would be viewed as another link in the dynastic chain which stretched back to the great founder of the dynasty himself - or perhaps, more importantly, to his mother Laodike. As the geography of the Hellenistic world changed during the later second and first centuries, the name Laodike retained its royal prestige, but ceased to be associated with the dynasty specifically - hence the sudden attestation of many women named Laodike that we shall discuss below.

This mechanism of transmission this aligns neatly with the categorising function that Calame describes is often at work with Greek personal names. The name Laodike confirmed the social status that family origin automatically conferred on the new-born child - in this case, the status of Seleukid royalty. But as we have seen earlier, this was only one of the many functions of Greek names, and thus this is only one side of the coin, as it were. To explore the deeper messages that are communicated by Seleukid female names, we shall now turn to the case study of Laodike and its myriad associations.

\section{The Perfect Name for a Seleukid: Laodike}

Considering the stemma of the Seleukids as a whole, it is interesting to note that in the longer history of the dynasty the name Laodike seems to have won out, as it were, against other female names: while early in the family's history we see the transmission of names like Apama, Stratonike, and to a lesser degree Antiochis, by the second century Laodike becomes popular to the point that most attested female Seleukids bear the name. Even the 'Ptolemaic' Kleopatrai name their daughters by Seleukid husbands Laodike as well, and from them the name is transmitted to Kommagene. ${ }^{37}$ Laodike thus becomes a fitting onomastic case study given its sheer prevalence in the dynasty, and I argue that the name is so popular because it conforms so neatly to many facets of Seleukid royal ideology particularly royal cult. To make the point, I shall consider the name on different levels.

First and foremost, the figure of Laodike, the mother of Seleukos I, is the anchor of the myth of Seleukos' divine descent from the god Apollo, which appears in Justin but was likely circulating earlier. ${ }^{38}$ The myth itself has been well discussed by Kyle Erickson and Daniel Ogden, and it seems likely that the role of Laodike as the literal conduit and

For instance, the daughter of Antiochos VIII Grypos and Tryphaina was named Laodike, as attested by Jos. AJ.13.13.4, Porphyry F $32.25-8$, and discussed by Bellinger 1949, 72. She would then go on to marry Mithridates I of Kommagene, and from there the name was transmitted throughout the dynasty. Earlier, the marriage of Kleopatra Thea to Antiochos VII Sidetes produced two daughters named Laodike, attested by Por. F32.20, Eus.Chron.1.257, and App.Syr.68. These two daughters named Laodike are attested as having died of disease at a relatively young age, Eus.Chron.1.257 = Por.F32.20, Bellinger 1949, 6on4. For the children of Kleopatra Selene, see Dumitru 2016.

38 In Justin 15.4.2-7: Huius quoque et uirtus clara et origo admirabilis fuit ; 3 siquidem mater eius Laodice, cum nupta esset Antiocho, claro inter Philippi duces uiro, uisa sibi est per quietem ex concubitu Apollinis concepisse, 4 grauidamque factam munus concubitus a deo anulum accepisse, in cuius gemma anchora sculpta esset, iussaque donum id filio, quem peperisset, dare. 5 Admirabilem fecit hunc uisum et anulus, qui postera die eiusdem sculpturae in lecto inuentus est, et figura anchorae, quae in femore Seleuci nata cum ipso paruulo fuit. 6 Quamobrem Laodice anulum Seleuco eunti cum Alexandro Magno ad Persicam militiam, edocto de origine sua, dedit. 
bearer of the dynasty's divinity is an aspect that would have been become more prominent in the tradition as the Seleukid cult increasingly emphasised the family's connections to Apollo. ${ }^{39}$ She is the last link in the dynastic chain, which in this mythological framework links the descendants of Seleukos to their divine ancestor. This is and of itself is ample cause to bequeath the name to subsequent generations of the dynasty, as it served as a potent reminder of the divinity of the bloodline.

But the name Laodike has much deeper apolline associations than just with the myth of Seleukos' descent, and over a longer period of time. In book four, Herodotus mentions how the inhabitants of Delos regularly honour the Hyperborean maidens Hyperoche and Laodike who, according to local myth, came to the island with five of their countrymen in order to bring offerings and gifts to the twin gods who were born there: Artemis and her brother Apollo. ${ }^{40} \mathrm{~A}$ few sections later the Historian also mentions how other Hyperborean maidens had come to Delos bearing tribute to Eilythia so that the pains of childbearing would be eased and their own fertility increased, so perhaps there is also a maternal valence to the later visit of Laodike to Delos in honour of the twin gods. ${ }^{41}$ Regardless, Herodotus' report that Laodike continued to be honoured in his day for this devotion to Apollo is apt testament to the longevity of these apolline associations, and the many other deities linked to Delos only serve to multiply these cultic connections of the name. The ancient idea of Hyperborea as a perfect land lying far to the north perhaps adds a geographical dimension to the name, thus linking Laodike to Macedon quite ambiguously, though this may be overly speculative. At any rate, this idea of Laodike as a dutiful mythical servant to the god Apollo at his birthplace is too congruent with Seleukid royal cult to be purely coincidental, it seems.

Homer, though, provides the most intriguing - and vexing - evidence for the many associations of Laodike. There are two women named Laodike who appear in the Iliad. The first is the Trojan princess, the daughter of Priam and Hekuba, and wife of Helikaon, who is recurrently described in books 3 and 6 as the fairest or the most beautiful of the daughters of Priam..$^{42}$ A link between the Seleukids and Asia Minor through the

39 On this myth see Ogden 2011, Erickson 2009, 39-42, and, most recently, Ogden 2016.

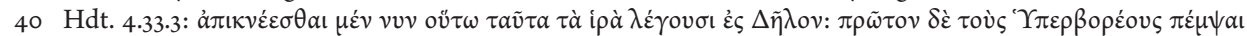

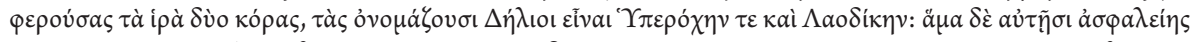

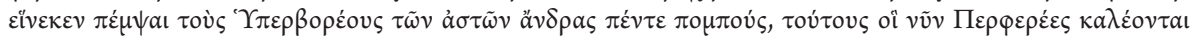

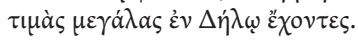

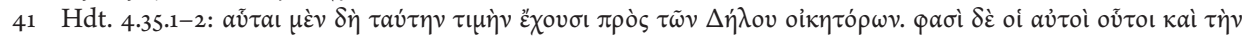

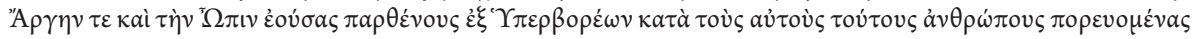

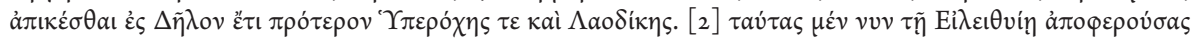

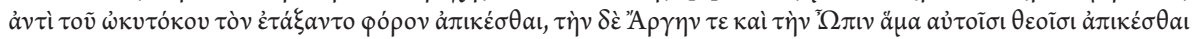

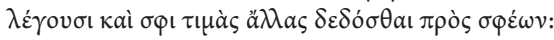

42 For this Laodike, see Hom.Il. 3.124 and 6.252. In Il. 3.121-124 Iris takes the form of Laodike: "I Ipıৎ $\delta$ '

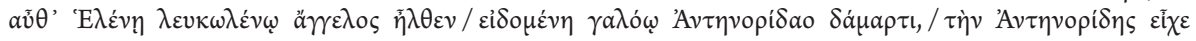

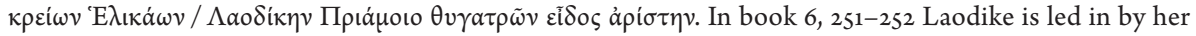

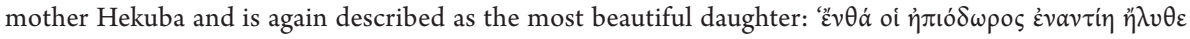

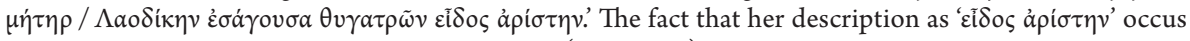
in the same metrical position and the same case (accusative) in both references to this Laodike make it

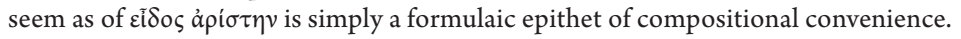


House of Priam is perhaps desirable, but likely not intentional. The goddess Iris takes the form of this Laodike when she travels as a messenger to Troy (3.121-124) in order to remind Helen of her homeland, her husband, and her family; a reminder which causes Helen to break down in remorse and wish that she died rather than come to Troy. This device functions on several levels: we can see Laodike as the bearer of the gods, quite literally, in this episode as Iris takes her form and uses her as a reminder to Helen of her maternal and nuptial duties. On a basic level, the identification of Laodike as the

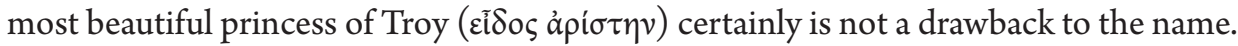
Elsewhere, in Lykophron, she appears as a dutiful wife and mother who takes her own life because of her grief for her family, and thus we find a recurring image of Laodike as a paragon of marital fidelity. ${ }^{43}$

The second Laodike appears somewhat later in the Iliad: the daughter of Agamemnon and Klytemnestra, who is mentioned along with her sister Chrysothemis and Iphianassa as part of the long list of benefactions Agamemnon would give to Akhilles as a dowry, if only he would return to the fight against Troy (9.145). This Laodike is again attested roughly a hundred and fifty lines later in a list of things belonging to Agamemnon, though the Poet gives no further detail about her ${ }^{44}$ Even with this vague detail, there still emerges an association between the name Laodike and the royal house of Argos, and perhaps this can be stretched further into an Argead connection given how frequently the Macedonians traced their descent to Argos - though this may be somewhat over-speculative, as Seleukid self-representation in the dynasty's early generations do not seem to promote a putative link to the Argeads..$^{45}$ An entry in Hesychios, however, complicates matters: according to the late-antique grammarian, this daughter of Agamemnon, Laodike, is known to later playwrights as Elektra, thereby opening an entire other realm of onomastic connotations. ${ }^{46}$ This equation of the two names, however, is

43 Lykophron, Alexandra 497. See also Tzetzes on Lykophron 314 and 495-497.

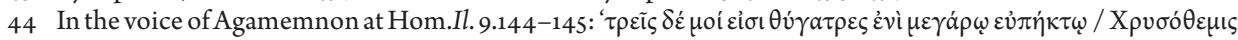

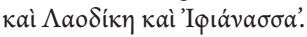

45 This consideration of Laodike's Argive descent also brings us to the important topic of the relationship between the Seleukids and the Argead house. It is noteworthy that unlike many of the other immediate Diadochoi and successor dynasties, the Seleukids do not immediately attempt to link themselves to royal house of Argead Macedon, or to the family of Antipater or Epirus, as Ptolemy I did with Eurydike (daughter of Antipater) and Berenike I, or Demetrios Poliorketes with Phila (daughter of Antipater), or Kassander with Thessalonike (daughter of Philip II). As Collins 1997 has shown, contemporary rumours circulated that Ptolemy I was possibly an illegitimate son of Philip II himself. With the Seleukids we do not find these overt links to the Argeads being cultivated: they claim descent from Apollo, not Zeus and Herakles who are more typically Argead figures, and Seleukos did not even figure among the various suitors of Kleopatra of Macedon, the only surviving full sibling of Alexander. While there are attestations of genealogical links between the Seleukids and Alexander the Great - and thus with the Argead house - in the Ahnengalerie of Nemrut Dag and with the claim that Seleukos I was a son of Alexander, and in Libanius Oration 11.91 with the purported link between the Seleukids and the Temenids, Strootman 2016, 217 note 22 argues that these are part of a much later tradition. This link to the Argeads, he writes, in agreement with Young 1996, 322-326, must belong to a much later time in which Alexander was connected to Hellenistic kingship more generally. This pseudo-Argead line is generally absent from Seleukid self-representation, especially during the early generations of the dynasty.

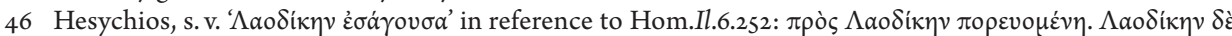
of $v \varepsilon \dot{\omega} \tau \varepsilon \rho \circ$ ' $H \lambda \dot{\varepsilon} \kappa \tau \rho a v \lambda \dot{\varepsilon} \gamma o v \sigma v v$. 
somewhat tenuous given that this is its only attestation, and the matter deserves to be the subject of another article entirely.

Finally, as we have seen above Greek personal names can often be linguistic compounds, and as with many other Homeric names it is revelatory to break Laodike down into its constituent parts. The meaning of the latter component of the name, dikē, is quite clear: justice, right, order, satisfaction, retribution, a kind of moral or social correctness or balancing. The former component is somewhat more ambiguous, and produces two possibilities: a noun in the genitive case, or a verbal form. As a noun the component lao can be taken as laos, and thus people, a community, ordinary men, or even the army, and it could be a possessive, objective, or even descriptive genitive governed by dikē. Taken together the two form a compound meaning something akin to 'the justice of the people, the dèmos', 'the order of the community'; the name reflects the civic, communal values in the same way as we have seen with female names in Alkman. The alternative possibility is to treat the component lao as a verb, thus dike becomes its transitive object and the meaning of the name changes somewhat. $L a \bar{o}$ is another first person form of blepō ('to behold', 'to look'), and in some Archaic and Doric contexts it can also mean 'to seize' or 'to hold', so the name can also be translated as 'I behold justice' or 'I see retribution. ${ }^{37}$ As with the name Andromache, in the case of one of our Homeric Laodikai, the daughter of Priam, this is ironic: just as Andromache does not actually destroy men, neither does the Trojan Laodike witness retribution or justice as her family and her city are destroyed by the invading Greeks, and she herself taken into slavery. Our other Laodike, the daughter of Agamemnon also known as Elektra, however, certainly does witness justice and obtains retribution as the transgressions of her mother are punished in the Oresteia.

In any event, the salient point is that there are manifold reading of these personal names, and I hope at least to have brought some potential associations of the name to light with this linguistic analysis. While Laodike is certainly a unique name when we consider how neatly it relates to Seleukid royal cult, the divine descent of the dynasty, and both the Hyperborean and Homeric women who previously bore the name, it is not exceptional among female names more generally, either within the dynasty or without. As with Antiochis, Kleopatra, or even Berenike, these names carry with them a wealth of connotations and are connected to various cultic, social, or religious traditions both in their contemporary context and the mythical or literary past. This examination of female names raises as many questions as it answers: when are these names given? Are they really the personal names of these royal women? Who receives them and who does not receive them, and why? It is to these pressing considerations that we turn in order to conclude this onomastic foray.

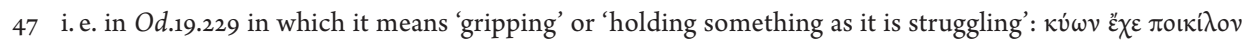

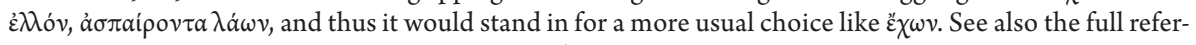
ences to different uses of the verb in LSJ s. v. ' $\lambda \dot{\alpha} \omega$ '. 


\section{Conclusions}

Unlike the relatively well-documented case of Olympias' many names that has been discussed above, there is only one attested case in which the name of a Seleukid woman was changed at marriage: the daughter of Kleoptolemos of Chalkis, whom he re-named Euboia in honour of the island of her birth. ${ }^{4}$ The change in name was, according to Athenaios, explicitly the decision of Antiochos III, not the young bride herself. The choice of Euboia is obvious given the king's desire to solidify his alliances in Greece against the Romans, and while this does seem to be an exceptional diplomatic marriage in the longer history of the Seleukid dynasty given its fairly immediate strategic concerns and the fact that she was not 'royal' herself, perhaps this can be put into a different pattern that sheds more light on how and when these royal women were named. What is noteworthy in the case of Euboia is the fact that no ancient sources mention the name by which she was known before her birth: she is only referred to as the 'daughter of Kleoptolemos' who was named Euboia by Antiochis. It is in this respect that she is similar to so many of her fellow Seleukid royal women.

The perennial problem in reconstructing the lives, families, and careers of royal women in the Seleukid dynasty and beyond is the fact that they tend only to be mentioned by our ancient sources at the time of their marriage and death, or in relation to the deeds of their children. Their birth and adolescence rarely grace the pages of our authors, and other references are generally limited to the generic, nameless children of a given king or queen. ${ }^{49}$ Therein lies the crux: I believe that this tendency of Seleukid royal women to only appear at the time of their marriage or when they become mothers along with the repetition of their personal names suggests that it was only at these moments in their lives that they became known by a 'regnal' or 'dynastic name like Laodike. In other words, it was only when they stepped fully into the public spotlight through a prominent diplomatic marriage and began taking part in the business of the dynasty that they were called by one of its trademark names. The same pattern, as we have seen above, is at work with the male members of the family who also adopted dynastic names at the time of their succession..$^{50}$

Laodike, then, along with names like Antiochis or Stratonike earlier in the dynasty's history, function as quasi-titles in the same way that Carney has described above. Laodike or any other Seleukid name by the second century thus becomes epithetical for not just 'royalty', 'queen', or 'princess', but specifically a Seleukid princess, replete with all divine ancestry and historical prominence associated with the family. From the reign of Antiochos III onwards, the name Laodike in particular became prominently associated would later marry Magas of Kyrene. This Apama is only attested when she is married by Paus. 1.7.3, and later appears in Justin 26.3.1-7 as the mis-identified 'Arsinoë'. The same is true of Stratonike who married Ariarathes of Kappadokia: she is first attested in Diodorus 31.19.6 at the time of her marriage, and is not attested again.

50 See the discussion of the names Seleukos and Antiochos above, as well as the above discussion of the exceptions to this trend in notes $23-25$. 
with the Seleukid dynasty. As infighting among rival male claimants to throne increased over the course of the second and first centuries and royal women increasingly acted as dynastic anchors securing the line while male relatives fought and died for the throne, it follows logically that rivals would emphasize their legitimate ties to the earlier generations of the dynasty, and thus the name Laodike perhaps recurred as a nod to continuity and stability amid the tumult of contested succession. ${ }^{51}$ This trend was perhaps also at work in the Ptolemaic dynasty: the name Kleopatra becomes the most popular name for Ptolemaic queens and princesses after the second half of the second century, although not to the exclusion of Arsinoë and Berenike, which remain names with connotations of Ptolemaic royalty. The idea that such names function as titles goes some way towards resolving the mystery of why so few women in the Seleukid realm were explicitly referred to as basilissa: if their personal name essentially already meant or at least implied queenship and royalty, then it would be somewhat redundant to add another title. This also explains why Seleukid client or vassal dynasts so eagerly imitated the female names of the family into which they married: having a wife named Laodike or Antiochis, for instance, by one's side had an immense ideological cachet in the realm of dynastic politics, and in turn would have generated a great deal of domestic prestige. These female names were repeated so frequently, in short, because they meant a great deal.

Accepting this plasticity of female names allows a broader reconstruction to be advanced. Whenever a female child was born into the dynasty she must have been given a personal name that she carried through childhood and adolescence; precisely what this was cannot be known because of the silence, ignorance, and perhaps disinterest of our sources on their early lives. The daughter would have been reared and educated in the court, and when she reached marriageable age either her brother or her father, whoever happened to be reigning over the Seleukid dominions at the time, would offer her in marriage to a key vassal or ally either in the Empire or beyond its borders. It was only then, when she left the dynasty's immediate oikos and entered the public sphere of Hellenistic politics as a scion of her natal house that she would have taken a name associated with the generations of royal women that had preceded her. ${ }^{52}$ This is precisely the same mechanism of onomastic transmission at the time of one's emergence into the public, royal sphere that has been identified by Lloyd Llewellyn-Jones $(2013,13-14)$ among the Achaemenid kings. ${ }^{53}$ In the early years of the dynasty this was Apama or Stratonike, each

It is for precisely this reason that Laodike IV figures so prominently in the public image of Antiochos IV,

52 This is a pattern that we see most prominently among the male names of the Achaemenid monarchs, whom Llewellyn-Jones 2013, 13-14 surmises adopted a new name at the time of their investiture as king in the presence of the magi, discarding their personal or familial names in favour of dynastically meaningful names rife with symbolism. This would seem to be the exact same principle at work with the women of the Seleukid dynasty, as I re-create this above. Subsequent conversations with Llewellyn-Jones has affirmed his hypothesis that this was the case among Achaemenid women as well, as we can see the similar repetition of names such as Atossa, Amestris, Stateira, although Brosius 1996 does not mention this pattern at all. Her sister Laodike, who married Mithridates II of Pontus, is likewise only attested when she is married: Eus.Chron.1.40.6, Justin 28.5.3.

53 See also the fragments of Ktesias cited by Llewellyn-Jones 2013, 13-14, which are included in the sourcebook section of his monograph. 
renowned and highly publicised queens in their own right, but as the generations of the dynasty passed on the name Laodike came into fashion as the links between Seleukos and Apollo were forged and tightened through the figure of his mother. So closely-woven was the Seleukid dynastic realm that some of these princesses would marry into a dynasty in far-flung Kappadokia or Pontus bearing their dynastic names, which would then be imparted on their daughters in turn. Generations later, as the name was passed from mother to daughter, some would even return home by marrying back into the family whence they had acquired their prestige and, perhaps most importantly, their title.

As these Laodikai went throughout the Empire, the name was transmitted to places and peoples who had no connection to this original lineage of queens, thus this along with other names such as Kleopatra cease to be tied to a specific dynasty and instead become generically royal or prestigious. Some 65 women named Laodike are attested over a period spanning six centuries from the dawn of the Seleukid dynasty to the reign of Hadrian, in places ranging from Campania to Greece, Thrace, the Aegean, and, of course, Asia Minor and Syria as well. ${ }^{54}$ This kind of onomastic imitatio regis, or perhaps more accurately, imitatio reginae is nothing unique to the Seleukids or even the Hellenistic world, but it does at least attest to the popularity and longevity of the name and its regal associations - even if they become less distinctly Seleukid over time. The same mechanism was likely at work with the name Kleopatra or Stratonike, which were in turn embedded with their own slate of linguistic, cultic, and literary signifiers. ${ }^{55}$ In this longer point of view, trying to trace the name precisely back to one originator or primeval figure, as it were, becomes futile. The mechanics of their transmission, however, along with the male names of each dynasty, merit further consideration as well.

But the point, I believe, remains: a personal name was far more than just a name, a rigid designator. In the case of female Hellenistic royalty a name was a vessel used to transmit the collective values, mythology, and history of a family along with the individuals of which it was composed. These names served to promote, to publicise, and, perhaps above if they are taken as quasi-titles, also to honour and revere the individual woman and the bloodline she represented. In the end, though, we are brought back to the words of Plato's Kratylos, who quite rightly asserted of such names as we have seen above that 'their function is to instruct, and that is the simple truth.'

54 And these are only the Laodikai attested in the LGPN. To replicate the search, please visit: http://claslgpn2.classics.ox.ac.uk/cgi-bin/lgpn_search.cgi?namenoaccents=\%CE $\% 9 \mathrm{~B} \% \mathrm{CE} \% 91 \% \mathrm{CE} \% 9 \mathrm{~F} \% \mathrm{CE} \% 94 \%$ $\mathrm{CE} \% 99 \% \mathrm{CE} \% 9 \mathrm{~A} \% \mathrm{CE} \% 97$

55 For instance, 202 women named Kleopatra are attested in the LGPN, and the name seems to become more popular in the Roman Imperial Period. The same is the case with Stratonike, which has 261 attestations. 


\section{Bibliography}

Ager, S. L.

2005: 'The Power of Excess: Royal Incest and the Ptolemaic Dynasty', Anthropologica 48, 165-86.

Almagor, E.

2016: 'Seleukid Love and Power: Stratonike I', in A. Coşkun and A. McAuley (eds), Seleukid Royal Women, Stuttgart, 67-86.

Ballesteros Pastor, L.

2008: 'Kappadokia and Pontus, Client Kingdoms of the Roman Republic from the Peace of Apamea to the Beginning of the Mithridatic Wars (188-89 BC)', in A. Coşkun (ed.), Freundschaft und Gefolgschaft in den auswärtigen Beziehungen der Römer (2. Jahrhundert v. Crh. 1. Jahrhundert n. Chr.), Mainz, 45-63.

Bennett, C. 2011: Ptolemaic Genealogy. http://www.reocities.com/christopherjbennett/ptolemies/ptolemies.htm

Bevan, E. R. 1902: The House of Seleucus, London. 1927: The House of Ptolemy, London.

Bielman-Sànchez, A.

2003: 'Régner au féminin. Réflexions sur les reines attalides et séleucides' in F. Prost (ed.) L'Orient méditerranéen de la mort d'Alexandre aux campagnes de Pompée, Rennes, 41-64.

Brosius, $M$. 1996: Women in Ancient Persia, Oxford.

Calame, C. 1977: Les choeurs de jeunes filles en Grèce archaïque, 2 vols, Rome. 1995: The Craft of Poetic Speech in Ancient Greece, Ithaka, N. Y.

de Callataÿ, F. and C. C. Lorber 2011: 'The Pattern of Royal Epithets on Hellenistic Coinage', in P. P. Iossif et al. (eds), More than Men, Less than Gods: Studies on Royal Cult and Imperial Worship, Leuven, 417-455.

Caltabiano, M. C. 1996: 'La basileia di Berenike II e il progetto di una diarchia', in L.Gasperini and S. M.Marengo (eds) Cirene e la Cirenaica nell'antichità: Atti del convengno internazionale di studi, Rome, 105-24. 1998: 'Berenice II. Il ruolo di una basilissa rivelato dalle sue monete', in E.Catani and S.M. Marengo (eds) La Cirenaica in età antica, Macerata, 97-112.

Cardona, G. R. 1980: Introduzione all'etno-linguistica, Bologna.

Carney, E. D. 1988: 'Eponymous Women. Royal Women and City Names', AHB 2.6, 134-42. 1991: "What's in a Name?” The Emergence of a Title For Royal Women in the Hellenistic Period', in S. B. Pomeroy (ed.), Women's History and Ancient History, Chapel Hill and London, 154-72.

1992: 'The Politics of Polygamy: Olympias, Alexander and the Murder of Philip', Historia 41, 169-89.

1994: Women and Monarchy in Macedonia, Norman.

1994: 'Olympias, Adea Eurydice, and the End of the Argead Dynasty', in I. Worthington (ed.), Ventures into Greek History, Oxford, 357-80.

1995: 'Women and Basileia: legitimacy and female political action in Macedonia', Classical Journal 90.4, 367-91.

2000: 'The Initiation of Cult for Royal Macedonian Women', Classical Philology 95: 21-43.

2006: Olympias. Mother of Alexander the Great, London

2011: 'Being Royal and Female in the Early Hellenistic Period', in A. Erskine and L. LlewellynJones (eds.), Creating a Hellenistic World, Swansea, 195-220. 
2012: 'Oikos Keeping: Women and Monarchy in the Macedonian Tradition', in S. L. James and S. Dillon (eds.), A Companion to Women in the Ancient World, Malden-Oxford, 304-15. 2014: Arsinoe II of Egypt and Macedon, Oxford.

Clayman, D. L.

2014: Berenice II and the Golden Age of Ptolemaic Egypt, Oxford.

Coloru, O.

2009: Da Alessandro a Menandro: Il Regno Greco Di Battriana. Pisa.

2011: 'The Language of Oikos and the Language of Power in the Seleucid Kindom', in R. Laurence and A. Stromberg (eds), Families in the Greco-Roman World, London, 84-94.

Coşkun, A.

2016: 'Laodike I, Berenike Phernophoros, and the Outbreak of the Third Syrian War (253-246)', in A. Coşkun and A. McAuley (eds), Seleukid Royal Women, Stuttgart, 107.

D’Agostini, M.

2013: Da Laodice I a Laodice III: l'orizzonte politico delle regine seleucidi, unpublished PhD Diss., Bologna.

2014: 'The Shade of Andromache: Laodike of Sardis between Homer and Polybios', AHB 28.12, 37-60.

2016: 'The Multicultural Ties of the Mithridatids: Sources, Tradition, and Promotional Image of the Dynasty of Pontus in $4^{\text {th }} 3^{\text {rd }}$ centuries BC.' Aevum 9o, $83-95$.

Forthcoming: 'Achaios the Younger and the Basileia of Anatolia: Observations on the Historiographical Tradition' in K. Erickson (ed.) War Within the Family: A Reassessment of the First Half-Century of Seleukid Rule, Swansea.

D’Agostini, M. and McAuley, A.

2012:'Achaeus the Elder' (2012); 'Alexander, Son of Achaeus the Elder'; 'Andromachus' (2012), on the website A. McAuley (ed.): Seleucid Genealogy. McGill University. URL: http://seleucidgenealogy.com/Achaeus.html (30 September 2014)

Dodd, R.

2009: 'Coinage and Conflict: The Manipulation of Seleucid Political Imagery', PhD dissertation, University of Glasgow.

Dumitru, A. G.

2016: 'Kleopatra Selene: A Look at the Moon and her Bright Side', in A. Coşkun and A. McAuley (eds), Seleukid Royal Women, Stuttgart, 253-272.

Dumke, G. R.

2013: 'Zierender Anhang oder eigenständige Kraft? Hellenistische Königinnen auf der großen Bühne, in C. Kunst (ed.), Matronage. Soziale Netzwerke von Herrscherfrauen im Altertum in diachroner Perspektive, Osnabrück, 51-56.

Dumke, G. R. \& K. Grigo.

2016: 'Ehefrau statt Mutter. Agathokleia und Straton I' in H. Schwarzer and H.-H. Nieswandt (eds) „Man kann es sich nicht prächtig genug vor-stellen!" Festschrift für Dieter Salzmann zum 65. Geburtstag, Marsberg/Padberg 2016, 49-60.

Durante, M. 1976: Sulla preistoria della tradizione poetica greca, Rome.

Engels, D. and K. Erickson 2016: 'Apama and Stratonike - Marriage and Legitimacy', in A. Coşkun and A. McAuley (eds), Seleukid Royal Women, Stuttgart, 39-66.

Erickson, $\mathrm{K}$.

2009: The Early Seleukids, Their Gods and Their Coins, Unpublished PhD Diss., University of Exeter.

Farney, G.

2007: Ethnic Identity and Aristocratic Competition in Republican Rome, Cambridge.

Forthcoming: Aristocratic Family Identity in Republican and Early Imperial Rome, in preparation. 
Grainger, J.D.

1990: The Cities of Seleucid Syria, Oxford.

1997: A Seleukid Prosopography and Gazetteer, Leiden.

2010: The Syrian Wars, Leiden.

Harders, A.-C.

2010: 'Hellenistische Königinnen in Rom', in A. Kolb (ed.), Augustae: machtbewusste Frauen am römischen Kaiserhof?

Herrschaftsstrukturen und Herrschaftspraxis II, Berlin, 55-74.

2013: 'Ein König und viele Königinnen? Demetrios Poliorketes und seine Ehefrauen' in C. Kunst (ed.), Matronage. Soziale Netzwerke von Herrscherfrauen im Altertum in diachroner Perspektive, Osnabrück, 43-50.

2016: 'The Making of a Queen: Seleukos Nikator and his Wives', in A. Coşkun and A. McAuley (eds), Seleukid Royal Women, Stuttgart, 25-38.

Heckel, W.

1981: 'Polyxena: The Mother of Alexander the Great', Chiron 11, 79-96.

Helliesen, J. M.

(1980): 'A Note on Laodice Number Twenty', CJ 75, 295-298.

Kajava, M.

1994: Roman female praenomina: Studies in the nomenclature of Roman women, Rome.

Kuhrt, A. and S. Sherwin-White

1991: 'Aspects of Seleucid Royal Ideology: The Cylinder of Antiochos I from Borsippa', JHS 111, $71-86$.

Llewellyn-Jones, L. 2013: King and Court in Ancient Persia 559 to 331 BC, Edinburgh.

Longega, G.

1968: Arsinoë II, Rome.

Macurdy, G.H.

1927: 'Eurydice and the Evidence for Woman Power in Early Macedonia', AJP 48, 201-14.

1932: Hellenistic Queens: A Study of Woman-Power in Macedonia, Seleucid Syria, and Ptolemaic Egypt, Baltimore.

McAuley, A.

2011: The Genealogy of the Seleucids: Seleucid Marriage, Succession, and Descent Revisited, http:// www.seleucid-genealogy.com.

2012: The Genealogy of the Seleucids: Seleucid Marriage, Succession, and Descent Revisited (MA dissertation: University of Edinburgh).

2015: 'Seeing through the Fog: Digital Problems and Solutions for studying Ancient Women', First Monday 20.4 (April).

2016: 'Princess and Tigress: Apama of Kyrene', in A. Coşkun and A. McAuley (eds), Seleukid Royal Women, Stuttgart, 175-190.

Mittag, P. F. 2006: Antiochos IV. Epiphanes. Eine politische Biographie, Berlin.

Mortensen, C. 1991: Olympias: Royal Wife and Mother at the Macedonian Court, Unpublished PhD Diss, University of Queensland, Brisbane, Australia.

Muccioli, F. 2013: Gli epiteti ufficiali dei re ellenistici, Stuttgart.

Mühlestein, $\mathrm{H}$. 1969: 'Redende Personennamen bei Homer', Stud. Mic. Egeo-anatol. 9, 67-94.

Müller, S. 2006: Das hellenistische Königspaar in der medialen Repräsentation. Ptolemaios II. und Arsinoë II. Berlin. 
Nagy, G.

1979: The Best of the Achaeans: Concepts of the Hero in Archaic Greek Poetry, Baltimore.

Nourse, K. L.

2002: Women and the Early Development of Royal Power in the Hellenistic East, PhD dissertation, University of Pennsylvania.

Ogden, D.

1999: Polygamy, Prostitutes and Death: the Hellenistic Dynasties, London.

2014: 'Seleucid Dynastic Foundation Myths: Antioch and Seleucia-in-Pieria', in K. Erickson and G. Ramsey (eds), Seleukid Dissolution: Sinking the Anchor, Wiesbaden, 149-160.

2016: 'Seleucus, his Signet Ring and his Tablet', in C. Bearzot and F. Landucci Gattinoni (eds.), Alexander's Legacy, Rome, 141-155.

Plischke, S.

2016: 'Apame und Stratonike - Die seleukidische Königin als Bindeglied zwischen West und Ost', in C. Binder et al. (eds), Diwan. Untersuchungen zu Geschichte und Kultur des Nahen Ostens und des östlichen Mittelmeerraums im Altertum. Festschrift für Josef Wiesehöfer, Duisburg, 325-346

Ramsey, G.

2016: 'The Diplomacy of Seleukid Women : Apama and Stratonike', in A. Coşkun and A. McAuley (eds), Seleukid Royal Women, Stuttgart, 87-106.

Risch, E.

1947: 'Namensdeutungen und Wörterklärungen bei den ältesten griechischen Dichtern', in Eumusia: Festgabe für E Howald zum 6o. Geburtstag, Erlenbach, 72-91. Also re-printed in Kleine Schriften, Berlin, 1988, 72-91.

Roller, D.

2010: Cleopatra: A Biography, Oxford.

Salway, B.

1994: 'What's in a Name? A Survey of Roman Onomastic Practice from c. 700 BC to A. D. 700 ', JRS 84, 124-145.

Schmitt, H.H.

1991: 'Zur Inszenierung des Privatlebens des hellenistischen Herrschers', in J. Seibert (ed), Hellenistische Studien. Gedenkschrift für Hermann Bengtson, Munich, 75-86.

Strootman, R.

2016: 'The Heroic Company of my Forebears: The Ancestor Galeries of Antiochos I of Kommagene at Nemrut Dagi and the Royal of Royal Women in the Transmission of Hellenistic Kingship', in A. Coşkun and A. McAuley (eds), Seleukid Royal Women, Stuttgart, 209-230.

van Dam, R.

2002: Kingdom of Snow, Philadelphia.

Wenghofer, R. and D. J. Houle

2016: 'Marriage Diplomacy and the Political Role of Royal Women in the Seleukid Far East', in A. Coşkun and A. McAuley (eds), Seleukid Royal Women, Stuttgart, 191-208.

Young, J.H

1996: 'Sculpture and Inscription Catalogue', in D. H. Sanders (ed.), Nemrud Daği: The Hierothesion of Antiochos I of Commagene. Results of the American Excavations Directed by Theresa B. Goell, Winona Lake, Vol. I, 175-360.

\section{ALEX MCAULEY}

School of History, Archaeology, and Religion, Cardiff University, Cardiff CF10 3 EU, Wales, UK, Mcauleya1@cardiff.ac.uk 